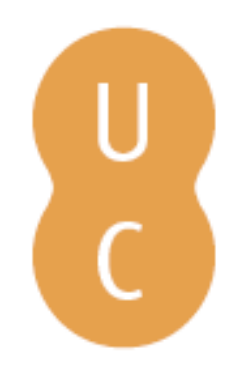

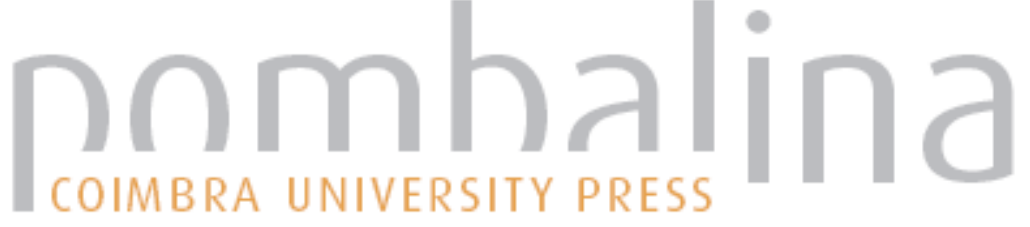

\section{Marcial e os banhos em Roma}
Autor(es):
Graça, Isabel
Instituto de Estudos Clássicos, Centro de Estudos Clássicos e
Publicado por: Humanísticos; Departamento de Estudos Clássicos, Centro de Estudos Clássicos

\author{
URL \\ persistente: \\ URI:http://hdl.handle.net/10316.2/34633 \\ DOI: \\ DOI:http://dx.doi.org/10.14195/978-989-26-0901-0_7
}

Accessed : $\quad$ 26-Apr-2023 16:24:46

A navegação consulta e descarregamento dos títulos inseridos nas Bibliotecas Digitais UC Digitalis, UC Pombalina e UC Impactum, pressupõem a aceitação plena e sem reservas dos Termos e Condições de Uso destas Bibliotecas Digitais, disponíveis em https://digitalis.uc.pt/pt-pt/termos.

Conforme exposto nos referidos Termos e Condições de Uso, o descarregamento de títulos de acesso restrito requer uma licença válida de autorização devendo o utilizador aceder ao(s) documento(s) a partir de um endereço de IP da instituição detentora da supramencionada licença.

Ao utilizador é apenas permitido o descarregamento para uso pessoal, pelo que o emprego do(s) título(s) descarregado(s) para outro fim, designadamente comercial, carece de autorização do respetivo autor ou editor da obra.

Na medida em que todas as obras da UC Digitalis se encontram protegidas pelo Código do Direito de Autor e Direitos Conexos e demais legislação aplicável, toda a cópia, parcial ou total, deste documento, nos casos em que é legalmente admitida, deverá conter ou fazer-se acompanhar por este aviso.

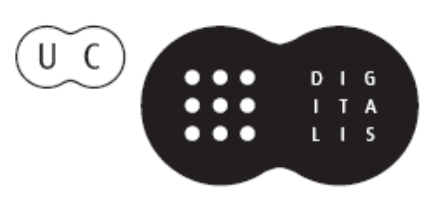




\section{Toto notus in orbe Martialis}

\section{Celebração de Marcial \\ 1900 anos após a sua morte}

Coordenação

Cristina de Sousa Pimentel

Delfim F. Leão

José Luís L. Brandão

Instituto de Estudos Clássicos

Centro de Estudos Clássicos e Humanísticos

UNIVERSIDADE DE COIMBRA
Departamentō de Estudos Clássicos Centro de Estudos Clássicos UNIVERSIDADE DE LISBOA 


\title{
MARCIAL E OS BANHOS EM ROMA
}

\author{
ISABEL GRAÇA \\ Universidade de Aveiro - Praxis XXI
}

\begin{abstract}
In the present work, we take as object of study the multiple literary references that are patent in Martial's Epigrams which are directly related with different forms of acting and interacting in the public baths of Rome, during the poet's stay in the heart of the City (from 64 to $98 \mathrm{AD}$ ). Starting from this work base, our objective is to analyse the manner in which he deals with the realities of the thermal spa and bathing in their physical, social, literary and cultural dimensions.
\end{abstract}

A generalidade da bibliografia crítica que consagra algumas reflexões sobre os centros de interesse do poeta Marcial faz referência à sua necessidade diária de ter de calcorrear diferentes caminhos, conducentes a diversas partes da cidade de Roma, com o intuito de dar cumprimento a todo um rol diversificado de tarefas quotidianas ${ }^{2}$. A observância dos deveres inerentes às práticas de clientela, entres os quais se destacava a passagem pelos potentiorum limina, tendo em vista a recolha da tão necessária espórtula, a passagem pelos livreiros, que colocavam os seus livros à disposição de eventuais compradores, e o gosto pela deambulação em meio urbano, vendo quem passa e quem pelas ruas se demora, eram apenas algumas das razões que levavam Marcial a percorrer diferentes

1 Enquanto Bolseira de Doutoramento ao abrigo do Programa Praxis XXI, registe-se o apoio financeiro por parte da FCT e do FSE, no âmbito do III Quadro Comunitário de Apoio.

2 São vários os epigramas que fazem referência a diversas tarefas que diariamente ocupavam o poeta. Cf. $8.44 ; 9.100 ; 10.10 ; 10.70$. 
recantos da cidade. Do Quirinal, onde residia, rumava a espaços tão diversos como o Aventino, o Esquilino, a região de além do Tibre, o Argileto ou a Suburra.

Para além destas áreas urbanas, um determinado espaço de Roma captava de forma muito particular a atenção do poeta, ao mesmo tempo que o seduzia a usufruir de um ócio deleitante: o Campo de Marte. Com efeito, o grande incremento paisagístico e arquitectónico aplicado ao Campus Martius, durante o período de vigência da dinastia Flávia, lograra oferecer à vista de todos uma admirável multiplicidade de avenidas, teatros, banhos públicos, pórticos e jardins.

A agenda social do poeta encaminhava-o para todos estes diferentes espaços de convívio e lazer. Aí encontrava gente da mais variada estirpe, cuja interacção produzia uma mescla de ruído, agitação e cor, vital para o carácter atractivo do "pulsar urbano" da capital do Império.

Será, pois, a partir deste enquadramento espacial e social, de cariz citadino, que intentaremos analisar algumas referências literárias aos banhos públicos de Roma, consagradas pelo poeta oriundo de Bílbilis nos seus famosos Epigramas.

Um primeiro aspecto que importará salientar prende-se com o facto de Marcial referir explicitamente os dois tipos de banho de acesso público existentes em Roma, durante o período de tempo em que por lá permaneceu: as thermae e os balnea $a^{3}$. Múltiplas vezes citados, aparecem referidos conjuntamente num total de seis epigramas, nos quais Marcial deixa perceber que se tratavam, efectivamente, de edifícios bastante semelhantes do ponto de vista funcional, dado encontrarem-se vocacionados para fins similares ${ }^{4}$.

${ }^{3}$ Este mesmo aspecto fora já salientado por Garrett G. FAGAN, Bathing in Public in the Roman World (USA, University of Michigan, 1999) p. 14.

${ }^{4}$ Citamos os versos dos Epigrammata Martialis a partir da edição de D. R. Shackleton Bailey (Londres, 1993). As traduções que apresentamos são da edição portuguesa: Marcial Epigramas, vols. I, II, III, IV, Edições 70 (Lisboa, 1999, 2000, 2001, 2004), introdução e notas de tradução de C. de S. Pimentel. 2.14.11-13: nec Fortunati spernit nec balnea Fausti / nec Grylli tenebras Aeoliamque Lupi: /nam thermis iterum ternis iterumque lauatur. «não despreza os banhos de Fortunato e de Fausto / nem o antro tenebroso de Grilo, nem o eólico de Lupo: / pois, nas termas, se lava e volta a lavar.»; 2.48.1,8: Coponem laniumque balneumque «Um taberneiro e um talhante e um balneário»; et thermas tibi haue Neronianas. «e guarda para Tito as termas neronianas.»; 3.20.15-16: Titine thermis an lauatur Agrippae / an impudici 
Deparamo-nos, no entanto, com alguns problemas quando procuramos identificar os aspectos que realmente os diferenciavam. A questão não é de fácil resolução. Garrett $\mathrm{G}$. Flagan confirma as muitas dificuldades na distinção clara dos referidos conceitos, no que concerne ao seu significado ${ }^{5}$. Apoiado em variadíssimos passos da Literatura Latina, o estudioso da matéria demonstra como a distinção entre thermae e balnea, tendo apenas por base o critério etimológico (as primeiras seriam aquecidas e as segundas não), se revela absolutamente falaciosa. De facto, as múltiplas referências literárias a balnea munidos de aquecimento jogam por terra o anterior critério distintivo. Mais recentemente, foi aventada a hipótese de a distinção assentar na ausência/presença nos banhos de um espaço destinado à actividade física (palaestra), possibilidade esta que pouca aceitação teve por parte da comunidade científica. Actualmente, a sugestão mais viável parece ser aquela que tem por base um duplo critério: a área espacial ocupada pelo edifício e o tipo de exploração a que se encontrava sujeito (pública ou privada). Assim, as thermae apareciam aos olhos de Roma como grandes construções edificadas à custa de capitais públicos, enquanto os balnea, de dimensões mais reduzidas, se encontravam na posse de entidades privadas.

Apesar de reconhecermos a importância desta variação terminológica e de aceitarmos que as duas palavras corresponderiam a duas imagens mentais distintas, não podemos todavia deixar de sublinhar um facto que se nos revela incontornável: a utilização, por vezes, indiferenciada de ambos os termos por parte de Marcial ${ }^{6}$.

balneo Tigillinni? «Banha-se nas termas de Agripa ou de Tito, / ou no balneário do torpe Tigelino?»; 7.34.10: thermas praefero balneis cinaedi. «Prefiro-as (termas de Nero) aos banhos de um paneleiro!»; 9.75.3,5-6,10: (...), Tucca balneum fecit: «Tuca um banho construiu:»; ut nauigare Tucca balneo possit.l Idem beatas lautus extruit thermas «Tuca, com um banho destes até pode navegar. / Mas, no seu requinte, construiu umas belas termas»; sed ligna desunt: subice balneum thermis. «Mas falta a lenha... Trata de pôr o banho debaixo das termas.»; 12.82.1-2: Effugere in thermis et circa balnea non est / Menogenem, omni tu licet arte uelis. «Nas termas e à volta dos banhos, é impossível evitar / Menógenes, mesmo que com toda a astúcia o queiras.».

${ }^{5}$ Op. cit., ibidem.

${ }^{6}$ A este propósito, a observação de F. SPOSI, «Archeologia e poesia in due epigrammi di Marziale (2, 14; 7, 73)», in Atene e Roma XLII-Fasc. 1, 1997, p. 21, nota 31, revela-se suficientemente ilustrativa: «È da sottolineare che in Marziale i termini balnea e thermae vengono usati indifferentemente (per citare solo 
O que não poderá igualmente ser olvidado é o facto de o poeta nos dar testemunhos vários acerca da pluralidade de ofertas balneares e termais, disponíveis em Roma no século I da nossa era.

Em 10.51.12, a expressão triplices thermae designa as Termas de Agripa, Nero e Tito, que aqui surgem cronologicamente citadas. Porém, não deixa de ser curioso notar que, se optássemos por referi-las tendo por base o critério da popularidade, a ordenação seria diversa.

No cimo do ranking dos banhos públicos com maior aceitação junto da população de Roma, encontravam-se as Termas de Nero, situadas no Campo de Marte, caracterizadas essencialmente pelo seu luxo e requinte. É de assinalar que também o bom aquecimento marcava pontos a seu favor. O epigrama 3.25, refere-as, a propósito da frieza dos lugares-comuns utilizados pelo retor Sabineio:

Si temperari balneum cupis feruens,

Faustine, quod uix Iulianus intraret, roga lauetur rhetorem Sabineium.

Neronianas is refrigerat thermas.

«Se desejas temperar um banho demasiado quente,

Faustino, no qual dificilmente Juliano entraria, pede ao retor Sabineio que aí se lave:

este até as termas neronianas refrigera.»

Num outro epigrama, que configura o género da uocatio ad cena (10.48.3-4), Marcial deixa perceber que, apesar de as frequentar, estas Termas seriam excessivamente quentes para os seus gostos?

temperat haec thermas, nimios prior hora unpores

halat, et immodico sexta Nerone calet.

alcuni esempi: Mart. 9, 75: ... Tucca balneum fecit: / sed strage nemorum pineaque compage; ... I Idem beatas lautus extruit thermas / de marmore omni... / Sed ligna desunt: subice balneum thermis; 3, 25: Si temperari balneum cupis feruens, / Faustine, ... I roga lauetur rhetorem Sabineium. / Neronianas is refrigerat thermas; 3, 36, 5-6: lasus ut in thermas decuma uel serius hora / te sequar Agrippae, cum lauer ipse Titi) ed interessante, a riguardo è anche la testemonianza di Gellio $(3,1,1)$ il quale com l'espressione balneas Titias, próprio come Marziale $(3,36,6)$, indica le terme di Tito.».

${ }^{7}$ Mas nem todos partilham os mesmos gostos. E ainda bem. Tudo indica que Fabiano as frequentava, a julgar sobretudo pelo conteúdo do quinto verso do epigrama 12.83 (in thermis subito Neronianis). 
«A esta hora tempera os banhos quentes, na hora anterior exala demasiados Vapores e, à sexta hora, abrasa nas de Nero.»

Menos populares em Roma eram os Banhos Públicos de Tito, situados nas proximidades do anfiteatro Flávio (Coliseu). No ranking, seguiam-se as Termas de Agripa, já bastante ultrapassadas. Tal como as de Nero, ficavam situadas no campo de Marte. Os últimos lugares da tabela eram ocupados por pequenos balnea, que, no entanto, vinham ganhando uma importância crescente na rotina diária dos habitantes da $\mathrm{Urbe}^{8}$.

Marcial apreciava os Banhos de Tito, mas também se vira obrigado a frequentar as Termas de Agripa, por serem da especial preferência de um dos seus patronos ${ }^{9}$. Os condicionalismos inerentes à prática de clientelismo assim o impunham.

Ainda relativamente a este aspecto, importará lembrar o epigrama 6.42, de claro teor laudatório. Indirectamente, Marcial elogia Cláudio Etrusco $^{10}$, seu amigo e patrono, pelos magníficos banhos que edificou na Urbe. As Etrusci thermulis eram, na verdade, quentes (vv. 3-7), luminosas (8-10) e luxuosamente requintadas nos seus mármores policromáticos

${ }^{8} \mathrm{O}$ anterior ranking foi estabelecido com base nos dados fornecidos por S. L. DysOn e R. E. PRIOR, "Horace, Martial, and Rome: two poetic outsiders read the ancient city" , Arethusa 28 (1995) 251-252.

${ }^{9}$ Referimo-nos a Fabiano. 3.36.1-2: Quod nouus et nuper factus tibi praestat amicus, / hoc praestare iubes me, Fabiane, tibi: «O que te faz um novo e recente amigo, / isto me obrigas, Fabiano, a fazer-te:»; 5-6: lassus ut in thermas decima uel serius hora / te sequar Agrippae, cum lauer ipse Titi. "que fatigado te siga, à hora décima ou até mais tarde, / para as termas de Agripa, embora me lave nas de Tito.». Cânio Rufo, escritor cuja obra não logrou chegar até nós era também amigo e patrono do poeta Marcial. Para além das Termas de Tito e de Agripa, Cânio Rufo era ainda frequentador dos Banhos de Tigelino. 3.20.15-16: Titine thermis an lauatur Agrippnelan impudici balneo Tigillini? «Banha-se nas termas de Agripa ou de Tito, / ou no balneário do torpe Tigelino?».

${ }^{10}$ Cláudio Etrusco fora igualmente patrono de um outro escritor afamado contemporâneo de Marcial: Estácio. Num passo de uma das suas obras, deparamo-nos com a mesma referência à sumptuosidade das referidas termas (Cf. Siluae 1.5). 
(vv. 11-15). Seriam, de facto, admiráveis, a ajuizar pelo carácter sublime da descrição:

Nullae sic tibi blandientur undae,

Non fontes Aponi rudes puellis, non mollis Sinuessa feruidique

fluctus Passeris aut superbus Anxur, non Phoebi uada principesque Baiae.

Nusquam tam nitidum uacat serenum:

lux ipsa est ibi longior diesque

nullo tardius a loco recedit.

Illic Taygeti uirent metalla

et certant uario decore saxa

quae Phryx et Libys altius cecidit,

siccos pinguis onyx anhelat aestus

et flamma tenui calent ophitae. ${ }^{11}$

«Nenhumas águas te afagam deste jeito,

nem as fontes de Ápono impróprias para moças,

nem a amena Sinuessa e, cálidas,

as águas do Pásser ou a Ânxur altaneira,

nem os banhos de Febo, nem Baias princesa.

Em nenhures o céu brilha tão transparente,

e até a luz é mais longa, e o dia

de lado algum se retira mais tarde.

Ali do Taígeto verdecem as jazidas,

com que rivalizam os blocos matizados

que bem fundo talham o Frígio e o Líbio.

O ónix opaco exala um calor seco

e com leve chama se aquentam os ófitos.»

Em alternativa a edifícios termais de aparência monumental, a população de Roma não raras vezes recorria aos balnea, acerca dos quais Marcial nos lega pouca informação. Alguns nomes aparecem ocasionalmente referidos: os Banhos de Dásio (2.52), os Banhos de Fausto e Fortunato (2.14.11), que juntamente com os Banhos de Lupo e Grilo (1.59.3; 2.14.12) poderiam ser talvez conhecidos como os "Quatro Balneários" (5.70.4), os Banhos de Tigelino (3.20.16), os Banhos de Carino (7.34) e os

$116.42 .3-15$. 
Banhos de Estéfano $(11.52 .4 ; 14.60)$. Se tomarmos como certa a interpretação proposta para o verso 11.52 .4 (scis quam sint Stephani balnea iuncta mihi.) avançada por Kay, que localiza os Banhos de Estéfano nas proximidades da casa do poeta, no Quirinal, torna-se fácil supor que Marcial seria seu frequentador assíduo ${ }^{12}$.

Fascinam-no os grandes aquedutos que providenciam o abastecimento de águas. Por diversas vezes, aparecem referenciadas nos Epigramas a Aqua Marcia ${ }^{13}$ e a Aqua Virgo ${ }^{14}$, obras de carácter monumental, verdadeiros portentos de engenharia e arquitectura Romanas ${ }^{15}$.

Familiarizado com todos estes espaços, que configuram alguns dos cenários do seu théâtre portatifí, Marcial tem-se revelado exímio na forma como explora toda uma gama diversificada de ambientes.

Os banhos de acesso público são um exemplo concreto do que acabámos de afirmar. Na verdade, são cenários que exalam cheiro, sobretudo, cheiro intenso a madeira queimada. Emergem uapores, o ruído e agitação são constantes, e aqueles que afluem aos banhos anseiam entregar-se aos seus múltiplos prazeres.

Gente que vem para ver e ser vista, gente que brada para se fazer ouvir, enfim, gente (toda a gente) pretende aceder aos banhos públicos.

${ }^{12}$ Cf. Kay, Martial Book XI (Londres, 1985) p. 182.

13 6.42.18: cruda Virgine Marciaue mergi «mergulhar na Virgem ou Márcia naturais»; 9.18.6: cum mihi uicino Marcia fonte sonet. "ressoe embora vizinho o cantar da fonte Márcia.»; 11.96.1: Marcia, non Rhenus salit hic, Germane (...) «É a água Márcia, e não a do Reno, que aqui brota, Germano (...)».

14 5.20.9: campus, porticus, umbra, Virgo, thermae «o Campo, os pórticos, a sombra, a Água Virgem, as termas»; 6.42.18: cruda Virgine Marciaue mergi «mergulhar na Virgem ou Márcia naturais»; 7.32.11: sed curris niueas tantum prope Virginis undas «é que tu preferes correr bem perto das frias águas da Virgem»; 11.47.6: perfundit gelida Virgine? (...) «mergulha na gelada Virgem (...)»; 14.163.2: Virgine uis sola lotus abire domum. «Só depois do banho na Virgem é que queres abalar para casa.».

${ }^{15}$ A respeito da construção de aquedutos e do abastecimento de água em Roma, veja-se o assinalável estudo de A. Trevor HODGE, Roman Aqueducts and Water Supply, (London, Duckworth, 1991).

${ }^{16}$ Expressão utilizada por Jean-Luc Hennig, no seu recente livro justamente intitulado Martial (Paris, Fayard, 2003) p. 312, para designar a totalidade dos Epigramas de Marcial. 
Um quadrante é o custo de entrada fixado para os homens ${ }^{17}$. Após uma breve passagem pelo apodyterium ou vestiário e tomadas as devidas precauções contra eventuais ladrões ${ }^{18}$, qualquer homem, independentemente da idade, poderá entregar a nudez do seu corpo aos prazeres da água e aos olhares de Lecânia: Sed meus, ut de me taceam, Laecania, seruus / Iudaeum nulla sub cute pondus habet, I sed nudi tecum iuuenesque senesque lauantur. (7.35.3-5) «Mas o meu servo, Lecânia, para já não falar de mim, / traz bem à vista um malho digno de um judeu, / e contigo lavam-se novos e velhos em pêlo.» ${ }^{19}$.

Se as crianças tinham entrada gratuita, já o tarifário das mulheres era ligeiramente superior ao dos homens (ligeiramente, se exceptuarmos o caso particular de Mamurra: «Sabe fazer as contas dos banhistas este Dásio. Pediu / à mamalhuda Espátale o preço de três: e ela pagou.»20).

17 3.30.4: Vnde datur quadrans? (...) «Donde te vem o quadrante (para o banho)? (...)»; cf. 3.42 .

18 A prevenção anti-roubo podia fazer-se de diferentes maneiras: recorrendo-se à utilização de cacifos, entregando os haveres ao cuidado de um escravo, ou então confiando as roupas a um dos capsarii (escravos ligados aos banhos que desempenhavam esta tarefa), o que poderia, ainda assim, constituir um risco. A este propósito, as palavras de Garrett G. Fagan, op. cit., p. 38, revelam-se extremamente oportunas: «It seems that where there were baths, there were thieves. This situation is an indirect testament to the popular and crowded nature of bathing establishments.».

19 A coincidência de pessoas de diferente sexo numa mesma sala de banho mereceu a atenção de Alain Malissard, no seu livro intitulado Les Romains et l'eau (Paris, Les Belles Lettres, 1994) p. 115: «(...) les balnea ne comportaient qu'une seule série de salles. On peut évidemment penser que certains d'entre eux $\mathrm{n}^{\prime}$ accueillirent qu'une clientèle exclusivement féminine ou qu'ils ouvrirent à des heures différentes, en réservant, par exemple, la matinée pour les femmes et l'après-midi pour les hommes; la mixité fut cependant presque toujours de règle, aussi bien dans les très grands, dont la structure était double, mais qui ne disposaient de toute manière que d'une seule et vaste salle froide équipée d'une piscine à l'air libre (...)». Importa, no entanto, sublinhar que, não raras vezes, as mulheres que frequentavam assiduamente os banhos mistos possuíam má reputação. A este propósito, veja-se o epigrama 3.72, dirigido a Saufeia.

20 2.52: Nouit loturus Dasius numerare. Poposcit/mammosam Spatalen pro tribus: illa dedit. 
A maioria das vezes, as mulheres tomavam banho nuas, facto que se encontra atestado no segundo verso do epigrama 3.3 (que é, no entanto, um epigrama de autenticidade duvidosa):

«Um formoso rosto com negro creme vais tapando, mas, com não formoso corpo, as águas tu ultrajas.

É a própria deusa, podes crer, que, pela minha boca, te diz:

'Ou mostras a cara, ou toma banho coberta com a túnica'.»

Por vezes, usavam um subligar, que na realidade consistia nuns mini-calções, reduzidos ao suficiente para encobrirem a nudez integral. Marcial refere-o de forma explícita no final do epigrama 3.87. Acusando, indirectamente, Quíone da prática de fellatio, o epigramatista declara:

«(...) tomas banho sem cobrir a parte que devias.

Se te resta algum pudor, desvia os calções para a cara.»

Independentemente das condições de acesso e permanência nos banhos de Roma, o percurso a realizar, no seu interior, era bem conhecido de todos. Após se terem desnudado, os homens sentavam-se nos bancos do tepidarium, onde a temperatura costumava oscilar entre os $25 \mathrm{e}$ os $30^{\circ}$. Iniciada a transpiração, os banhistas passavam a uma sala mais quente, designada sudatorium, no caso de o calor ser seco, ou laconicum (nome que advém da sua origem lacedemónia), no caso de se tratar de calor húmido. Só posteriormente entrariam no caldarium que, na maioria das vezes, exibia uma forma rectangular. Era aí que se encontrava uma grande banheira ${ }^{21}$, onde a água era mantida a $40^{\circ}$. A dificuldade em tolerar o calor excessivo era de alguma maneira controlada através do recurso à aspersão de água fria emanada do labrum, situado numa das suas extremidades ${ }^{22}$.

Não se julgue, porém, que uma ida aos banhos se resumia a um percurso tão simples e tão pouco variado. Nada disso. Antes do banho propriamente dito, as salas para práticas desportivas (sphaeristerium) eram ocupadas por alguns frequentadores, que praticavam jogos com bola

${ }^{21}$ Este local apresentava várias designações: alueus, descensio, solium ou baptisterium.

22 Para mais informação, veja-se A. Malissard, op. cit., pp. 113-120. 
(pila), e pelo público assistente, que se comprazia na observação dos corpos atléticos em todo o seu esplendor. O trigon era um dos vários jogos praticados e para o qual eram necessários, tal como o nome indica, três jogadores, colocados em posição triangular. Estava na moda, durante o período de vigência de Nero. Uma pequena bola, extremamente dura, é lançada com uma mão à esquerda ou à direita, com toda a força e sem pré-aviso.

À semelhança do que hoje acontece, diferentes práticas desportivas requeriam diferentes tipos de bola. O harpastum era a bola disputada por dois grupos, constituídos por um número indefinido de jogadores, que se esforçavam por conseguir apanhá-la do chão, para imediatamente a passarem aos companheiros ${ }^{23}$. São evidentes, sem dúvida, as parecenças com o actual râguebi! O follis, também designado folliculus, era uma grande bola, feita de couro, podendo também ser uma bexiga cheia de ar, leve como uma pluma, à semelhança dos balões dos nossos dias e das bexigas de porco usadas nas nossas aldeias há relativamente pouco tempo. Proporcionava exercícios mais leves e, como tal, era da especial preferência das crianças e dos idosos ${ }^{24}$. Marcial esteve lá, viu e registou:

\section{(...) tepidumue trigona}

siue harpasta manu puluerulenta rapis

plumea seu laxi partiris pondera follis ${ }^{25}$

«(...) quer a pela que aquece

ou as bolas empoeiradas com a mão apanhes,

quer partilhes a massa plumosa do lasso fole»

23 14.48: Haec rapit Antaei uelox in puluere draucus, / grandia qui uano colla labore facit.«Arrebata-as, na arena de Ateneu, o lesto atleta / que cria, com insensato esforço, um desmedido colo.».

${ }^{24}$ 14.47: Ite procul, iuuenes: mitis conuenit aetas: / folle decet pueros ludere, folle senes. «Ao largo, jovens: convém-me uma dócil idade. / Ao fole devem jogar os meninos; ao fole, os velhos.».

25 4.19.5-6. A alusão ao trigon está também presente em 7.72.9-11: Sic palmam tibi de trigone nudo / unctae det fauor arbiter coronae / nec laudet Polybi magis sinistras: "Que o juízo favorável dos circunstantes ungidos / te conceda a vitória na pela desnuda / e não louve mais a esquerda de Políbio.»; 14.46: Si me molibus scis expulsare sinistris, / sum tua. Si nescis, rustice, redde pilam. «Se me sabes repelir com tuas lestas esquerdas, / sou tua. Se não sabes, cepo, devolve a péla.». 
Marcial faz ainda referência à pila paganica, semelhante a uma bola rústica, também ela utilizada enquanto elemento proporcionador da prática de exercício físico ${ }^{26}$.

Como podemos facilmente verificar, o poeta focaliza a sua atenção em diversos tipos de exercício físico desenvolvidos nos banhos, em espaço próprio destinado para esse efeito. Marcial capta o calor produzido na mão do jogador, centra a sua atenção no pó que reveste a péla, coloca em primeiro plano a mão que imediatamente a agarra. Passe o anacronismo, Marcial dedica-se à "filmagem cinematográfica" de cenas do quotidiano decorridas em ambiente termal, procedimento este directamente relacionado com a opção clara do poeta por uma estética de pendor realista.

Não se julgue, porém, esgotado o rol de actividades físicas praticadas em espaço termal. O levantamento de halteres não estava ao alcance de todos, dado constituir um exercício pesado para braços efeminados ${ }^{27}$; o "esgrimir" de armas de lâmina de encontro a um tronco de dois metros de altura era uma outra prática a que se podia assistir ${ }^{28}$. Sobretudo os jovens exercitavam-se no pancrácio, ou às mãos de um mestre de boxe, cuja «orelha ratada» a todos lembrava os ferimentos provocados no decorrer da luta livre ${ }^{29}$. Os corpos, nus, apresentavam-se untados de ceroma (ou ceromata), um unguento composto a partir de uma mistura de cera e azeite, podendo também incorporar borras de vinho ${ }^{30}$.

267.32 .7 : non pila, non follis, non te paganica thermis «Nem a péla, nem a bola, nem a pelota rústica nas termas»; 14.45: Haec quae de facili turget paganica pluma, I folle minus laxa est et minus arta pila. «Esta camponesa que está cheia de macias penas / é menos lassa que um fole e menos compacta que uma bola.».

27 7.67.5-6: (...) grauesque draucis / halteras facili rotat lacerto «(...) faz girar, com braço ágil, / os halteres muito pesados para os efeminados».

${ }^{28}$ 7.32.8: (...) nudi stipitis iuctus hebes «o golpe rombo contra um tronco nu».

29 7.32.5: at iuuenes alios fracta colit aure mngister «Mas dos outros jovens cura um mestre de orelha ratada».

30 4.4.10: (...) ceromata faece de Sabina, «os emplastros de borras da Sabina»; 4.19.5: (...) lentum ceroma teris (...) «(...) o macio unguento esfregues (...)»; 7.32.9: uara nec in lento ceromate bracchia tendis, «nem os braços arqueados, envoltos em macio unguento, estendes»; 11.47.5-6: Cur Lacaedemonio luteum ceromate corpus / perfundit gelida Virgine? (...) «Porque mergulha ele o corpo recoberto de unguento / da Lacedemónia na gelada Virgem? (...)». 
Respirava-se uma atmosfera plena de sedução: a macieza dos corpos aliava-se ao brilho do suor deslizante. Filénis, adepta de práticas lesbianas, harpasto quoque subligata ludit / et flauescit haphe ${ }^{31}$ («cingida, joga também à bola e fica amarela com o pó»). Haphe era, na realidade, o pó com que os atletas se esfregavam antes do confronto físico. Terminado este, $\mathrm{e}$ após o banho, a strigilis, espécie de almofaça (escova de ferro), percorria o corpo, proporcionando uma esfoliação da pele. O seu uso revelava-se vantajoso não apenas para o próprio utilizador. O epigrama 14.51, justamente intitulado Strigiles, aduz informação pertinente: Pergamon has misit. Curuo destringere ferro: / non tam saepe teret lintea fullo tibi. («Pérgamo as enviou. Limpa-te com a curva lâmina. / Com tanta frequência não desgastará o pisoeiro as tuas toalhas.»).

Em contexto termal, as massagens constituíam também uma prática corrente, para a qual se exigia pessoal competente e especializado. Segundo nos diz Marcial, a já referenciada Filénis, conhecida por evidenciar um comportamento totalmente inadequado à sua condição de mulher, não resistia a entregar-se às mãos de um qualquer massagista ${ }^{32}$. O certo é que à custa de fricções e compressões musculares, tendo em vista a obtenção de resultados terapêuticos, havia alguns que chegavam a fazer fortuna à custa disso. ${ }^{33}$

Para além de toda esta diversidade de actividades ligadas, quer à higiene, quer ao bem-estar físico da população em geral, a presença constante em determinados espaços balneares e termais prendia-se também com uma importante função social: estabelecer contactos interpessoais que favorecessem o surgimento de um convite para jantar. É este o caso paradigmático de Sélio, personagem que tipifica os cidadãos parasitas de Roma, que proliferavam do século I. No epigrama $2.14^{34}$, nos versos 11 a 13, Sélio percorre uma variedade incrível de locais públicos (diversos pórticos, um teatro e zonas verdes envolventes, termas e

31 7.67.4-5.

32 7.67.8: uncti uerbere uapulit magistri «aos rudes golpes se entrega do massagista untado.».

33 7.32.6: et rapit immeritas sordidus unctor opes. «e deles o sujo massagista saca uma fortuna imerecida».

${ }^{34}$ No artigo atrás citado da investigadora Federica SPOSI, o epigrama 2.14, entre outros passos da Literatura Latina, surge-nos como um importante documento ao serviço da reconstrução arqueológica da Urbe do tempo dos Flávios. 
balnea), que lhe permitiam "caçar" um convite para participar num banquete $^{35}$. No que respeita particularmente à passagem pelos banhos, Marcial adequa o tratamento formal dos versos à situação caricata da personagem visada. Vejamos:

nec Fortunati spernit nec balnea Fausti

nec Grylli tenebras Aeoliamque Lupi:

nam thermis iterum ternis iterumque lauatur.

«Não despreza os banhos de Fortunato e de Fausto

nem o antro tenebroso de Grilo, nem o eólico de Lupo:

pois, nas termas se lava e volta a lavar.»

Do ponto de vista estilístico, a anáfora (nec... nec.../nec...) acentua o carácter repetitivo da acção de Sélio, apostado em conseguir um convite para jantar. Não menos expressiva é a aliteração da consoante linguodental surda / $t$, a sugerir a reiteração das suas idas às termas; para o mesmo efeito, concorre a repetição iterum... iterumque, presente no mesmo verso. A este propósito, torna-se ainda interessante notar o facto de a forma verbal lauatur, colocada em final de verso, interromper subitamente a manifesta prevalência da sonoridade nasal que nele se fazia sentir. As duas vogais abertas $(/ \mathrm{a} /$; /a/), incluídas na palavra que remata o

${ }^{35}$ A referida temática da deslocação aos banhos, entre outros destinos, com o intuito de provocar o encontro com alguém que ofereça um convite para jantar, está também presente noutros epigramas, facto que nos remete para o carácter recorrente deste tipo de prática em Roma, durante o século I da nossa era. Cf. 5.44.1-6: Quid factum est, rogo, quid repente factum est, / ad cenam mihi, Dento, quod uocanti - I quis credat? - quater ausus es negare? / sed nec respicis et fugis sequentem, I quam thermis modo quaerere et theatris / et conclauibus omnibus solebas. «Que sucedeu, pergunto, que de repente sucedeu, / pois que a mim, ó Dentão, quando te convidava para jantar / - quem vai acreditar? -, quatro vezes ousaste dizer que não? / Mas nem olhas para trás e foges de mim quando te persigo, / de mim, a quem, ainda há pouco, por termas, teatros / e por todas as reuniões costumavas procurar." ; 12.82.1-2: Effugere in thermis et circa balnea non est / Menogenem, omni tu. licet arte uelis. «Nas termas e à volta dos banhos, é impossível evitar / Menógenes, mesmo que com toda a astúcia o queiras.»; 13-14: omnia laudabit, mirabitur omnia, donec / perpessus dicas taedia mille 'ueni!' «Tudo há-de louvar, há-de admirar tudo, até que... / tu, farto já de mil chatices, lhe digas "Anda jantar!".». 
verso, sugerem, pois, julgamos que de forma inequívoca, o espanto e a admiração do poeta pelo comportamento deplorável do indivíduo parasita ${ }^{36}$.

Ao que tudo indica, não raras vezes, outras "voltas" davam os olhos daqueles que tomavam a iniciativa de convidar alguém para jantar. O epigrama 1.23 revela-se bastante esclarecedor:

Inuitas nullum nisi cum quo, Cotta, lauaris

et dant conuiuam balnea sola tibi.

mirabar quare nunquam me, Cotta, uocasses: iam scio me nudum displicuisse tibi.

«Não convidas para jantar, Cota, senão um companheiro de banho e só os balneários te fornecem os convidados.

Admirava-me eu, Cota, porque nunca me convidavas: Agora sei que eu, nu, não te agradei.»

O último verso da composição é aquele onde surge a justificação para o facto de Cota jamais ter lançado um convite ao poeta. Em destaque, precisamente a meio do verso, encontra-se o adjectivo que motivou tal situação: nudum. Com efeito, a nudez física do poeta jamais suscitara qualquer tipo de agrado aos olhos de Cota.

O remate da composição não é mais do que um eco da melancolia do poeta (iam scio me nudum displicuisse tibi.), que imprime a sua tristeza na oclusão das vogais, guardando na lembrança o repúdio a que fora votado.

A situação descrita neste último epigrama serve ainda para nos ajudar a compreender a importância dos banhos de acesso público, enquanto espaço potenciador de interacções de natureza social e sexual.

${ }^{36}$ A tradução que apresentamos para este mesmo verso merece também ser considerada. Note-se que o tradutor, ciente da presença assídua de Sélio nas termas, podendo optar por traduzir iterum... iterumque por "várias vezes", preferiu empregar a expressão «lava e volta a lavar». Não deixa de ser surpreendente como a alternância consecutiva dos fonemas /1/ e /v/ concorre para veicular a mensagem que se pretende transmitir, sugerindo, uma vez mais, o tempo dispendido por Sélio e as voltas que se vê obrigado a dar, na esperança de concretizar o seu objectivo. 
Em muitas situações, o gesto, a atitude e o comportamento são inteiramente condicionados por um interesse particular, que orienta a atenção do indivíduo para actos específicos, como a "caça" ao convite para jantar. Não raras vezes, o interesse é diverso, revestindo-se de uma componente de cariz sexual. Exemplo disso são os versos 10 a 14 do epigrama 11.96:

Rogabit unde suspicer uirum mollem.
Vna lauamur: aspicit nihil sursum,
sed spectat oculis deuorantibus draucos
nec otiosis mentulas uidet labris.

«Ele perguntará donde me vem a suspeita de que o tipo é maricas.

Tomamos banho juntos: ele nunca olha para cima, mas observa, com olhos devoradores, os sodomitas, e não olha os seus membros com lábios indiferentes.»

Para onde se olha, como se olha e o que se olha tornam-se aspectos relevantes em ambiente balnear. Com efeito, os banhos de Roma configuravam um espaço público com características particulares, que favoreciam como nenhum outro a observação/apreciação de corpos, em estado de nudez. Em 3.68.3-4, as palavras do poeta, que servem de advertência à matrona, vão de encontro ao que acabámos de afirmar:

Gymnasium, thermae, stadium est hac parte: recede.

Exuimur: nudos parce uidere uiros.

«O ginásio, as termas e o estádio estão nesta parte: retira-te.

Vamo-nos despir: dispensa-te de ver homens nus.»

A realidade descrita nos Epigramas permite-nos concluir que, em contexto balnear, manifestações de voyeurismo eram, de facto, correntes. Tal como é lícito pensar, este tipo de atitudes, que no contexto em análise se traduzem na observação da nudez alheia, ocorriam quer nos banhos públicos destinados a pessoas de um mesmo sexo, quer nos designados banhos mistos. Nos primeiros, favoreciam-se os contactos de natureza homossexual; nos segundos, promoviam-se aproximações de cariz heterossexual. 
A julgar pelo conteúdo do epigrama 11.63, Marcial não vê com bom olhos determinado voyeurista, entusiasmado com os dotes físicos dos seus jovens escravos:

\author{
Spectas nos, Philomuse, cum lauamur, \\ et quare mihi tam mutuniati \\ sint leuis pueri subinde quaeris. \\ Dicam simpliciter tibi roganti: \\ pedicant, Philomuse, curiosos.
}

«Pões-te a olhar para nós, Filomuso, durante o banho:

e porque serão os meus escravos tão avantajados

e lisinhos sem cessar perguntas.

Vou responder com franqueza à tua questão:

É que eles enrabam, Filomuso, os curiosos.»

Mas nem só a observação descarada da nudez alheia é digna de condenação. Marcial aproveita o espaço termal e balnear para criticar uma outra maleita social não menos reprovável: a presunção. O epigrama 11.59 é um bom exemplo do que acabámos de afirmar:

Senos Charinus omnibus digitis gerit

nec nocte ponit anulos

nec cum lauamur. Causa quae sit quaeretis?

Dactyliothecam non habet.

«Carino traz em cada um dos seus dedos seis

anéis e nem de noite os tira,

nem quando toma banho. Porque será perguntarão?

Não tem cofre para os guardar.»

Uma outra situação, decorrida em contexto termal, merece-nos igualmente atenção. Referimo-nos à situação particular dos Judeus que, pelo facto de serem circuncidados, tinham fama de possuírem órgãos sexuais de grandes dimensões. Irresistivelmente apetecíveis aos olhos dos mais depravados, suscitaram também um interesse especial por parte do poeta, como facilmente podemos comprovar através da leitura dos epigramas 7.35 e 7.82 . 
Inguina succinctus nigra tibi seruus aluta stat, quotiens calidis tota foueris aquis.

Sed meus, ut de me taceam, Laecania, seruus

Iudaeum nulla sub cute pondus habet,

sed nudi tecum iuuenesque senesque lauantur.

An sola est serui mentula uera tui?

Ecquid femineos sequeris, matrona, recessus, secretusque tua, cunne, lauaris aqua?

«De material apanhado em negro couro, ao teu pé um servo estaca, sempre que por inteiro em quentes águas te comprazes.

Mas o meu servo, Lecânia, já para não falar de mim, traz bem à vista um malho digno de um Judeu,

contigo lavam-se novos e velhos em pêlo.

Será que só o teu servo tem uma verga a sério?

Será que te afastas, matrona, para algum retiro de mulheres e em segredo, cona, te lavas em água que é só tua?»

Menophili penem tam grandis fibula uestit ut sit comoedis omnibus una satis.

hunc ego credideram - nam saepe lauamur in unum sollicitum uoci parcere, Flacce, suae:

dum ludit media populo spectante palaestra, delapsa est misero fibula: uerpus erat.

«É tamanha a fíbula que o pénis de Menófilo cobre, que ela só bastaria para todos os comediantes.

Eu pensava - já que amiúde nos lavamos em conjunto -

Que a sua preocupação, Flaco, era poupar a voz.

Mas quando jogava, no meio da palestra e com todos a ver, Escorregou a fíbula ao infeliz: era circuncidado.»

Relativamente a estes dois epigramas, importará realçar que, em ambos os casos, a extraordinária dimensão do órgão sexual masculino é sempre o elemento mais destacado. Em 7.35, esta alusão surge sensivelmente a meio do poema (v. 4); no epigrama 7.82, a crença no facto de as descomunais dimensões dos órgãos sexuais dos Judeus advirem da circuncisão encontra-se registada nos dois versos iniciais da composição.

Uma leitura atenta do anterior epigrama poderá ainda fazer-nos questionar acerca das verdadeiras razões justificativas da manutenção da 
fíbula por parte dos Judeus, em espaço balnear e termal. Ao contrário do que poderíamos inicialmente supor, não se trata apenas de pudor, nem resulta de simples atitude de precaução para não ferir a decência. Outros motivos, explicáveis sobretudo à luz de certos condicionalismos sócio-políticos, subjazem à evidência de tal comportamento.

Há que salientar que, na poesia de Marcial, os Judeus não são os únicos a apresentarem-se portadores de fíbula. Actores, citaristas e flautistas aparecem igualmente referenciados ${ }^{37}$. Consistindo num anel de metal preso ao prepúcio para evitar a erecção ${ }^{38}$, a fibula significaria a interdição de práticas sexuais, que, segundo se acreditava, lhes diminuiriam o vigor, podendo inclusive provocar-lhes alterações de voz ${ }^{39}$.

Por outro lado, determinados passos da poesia de Marcial ajudam a sustentar a hipótese de que a apresentação, em público, da fíbula não seria mais do que uma forma de publicidade às dimensões $X X L$, que caracterizariam os órgãos sexuais dos Judeus circuncidados. Poderiam, assim, exigir um maior pagamento pelos serviços de natureza sexual eventualmente prestados ${ }^{40}$. Eram as regras do mercado a funcionar: maior inflação do pénis, maior custo para o consumidor.

No entanto, teremos ainda de considerar uma outra razão que, como veremos, se apresenta bastante plausível. Iremos, descortiná-la a partir do verso final do epigrama 7.82: delapsa est misero fibula: uerpus erat. («escorregou a fíbula ao infeliz: era circuncidado»). Por que razão o poeta caracteriza Menófilo de miser, se, na verdade, era sexualmente tão bem

37 11.75.1-3: Theca tectus ahenea lauatur / tecum, Caelia, seruus; ut quid, oro, I non sit cum citharoedus aut choraules? «Tapado por um estojo de bronze, contigo / se banha, Célia, o teu escravo. Para quê, pergunto, / se ele não é citaredo nem flautista de coro?»; 14.215: Dic mihi simpliciter, comoedis et citharoedis, / fibula, quid praestas? 'carius ut futuant.' «Diz-me com franqueza, fíbula: de que serves / a comediantes e citaredos? «Para foderem mais caro.»».

38 Cf. Celso, 7.25.2; N. Kay, Martial. Book XI: A Commentary (Londres, 1985), p. 229.

${ }^{39}$ Cf. N. Kay, op. cit., p. 230.

${ }^{40}$ Em primeiro lugar, seria necessário pagar ao ferreiro o serviço de retirar a fíbula. 9.27.12: refibulauit turgidum faber penem «e desafivelado pelo ferreiro»; só então estariam aptos para a prática sexual. Cf. 14.215. 
dotado? A queda da fíbula foi como o retirar involuntário da máscara. Na verdade, a forma adjectiva traduz o preconceito romano contra os Judeus, o qual se viu acentuado a partir da destruição de Jerusalém em 70 d. C., acontecimento que os conduziu à diáspora. Tito tomara as rédeas desta devastadora campanha, tendo obrigado os Judeus ao pagamento de um elevado imposto (duas dracmas): o fiscus Iudaicus ${ }^{41}$. Marcial não se mostra alheio a este aspecto do direito fiscal Romano. Prova disso é o modo como em 7.55.8 caracteriza o pénis de um Judeu: damnatam modo mentulam tributis. («essa verga condenada há pouco a pagar imposto.»).

Para além de proporcionar informações colaterais relativas a aspectos jurídicos e sócio-culturais da sociedade Romana de que era parte integrante, Marcial explora ainda o espaço balnear e termal, intentando "pôr a nu" certas atitudes viciosas, nada recomendáveis, que por lá se deixavam ver.

A gula, por exemplo, não escapou ao olhar atento do poeta. No epigrama 12.19, Marcial ironiza com o apetite devorador de Emílio: In thermis sumit lactucas, oua, lacertum, I et cenare domi se negat Aemilius («Nas termas come alface, ovos, cavala. / e diz o Emílio que não janta em casa!»). O excesso de bebida alcoólica aparece, por sua vez, censurado em 12.70.8: sobrius a thermis nescit abire domum («das termas para casa já não sabe tornar sóbrio.»).42

Há também personagens que tipificam não um, mas uma súmula de vícios. Nesta matéria, Zoilo revela-se exemplar. A prova disso está no epigrama 2.42: Zoile, quod solium subluto podice perdis, / spurcius ut fiat, Zoile, merge caput. ( «Zoilo, porque conspurcas a banheira ao lavar o traseiro? / para ficar mais imunda, Zoilo, mergulha a cabeça.»). Habilidosamente, o poeta levanta a insinuação de práticas sexuais obscenas pratica-

${ }^{41}$ Cf. C. Pimentel (coord. e notas), Marcial, Epigramas, vol. III, pp. 36-37, nota 14. Uma informação mais detalhada sobre o imposto em causa poderá ser consultada em Margaret H. Williams, The Jezus among the Greeks E Romans. A Diasporan Sourcebook (London, 1988) pp. 100-105.

${ }^{42}$ Garrett G. Fagan, op. cit. p. 33, refere vários dados que permitem afirmar que, de facto, era possível consumir bebidas e comer refeições de tipo snack, em espaço termal, mediante determinado pagamento. 
das pelo seu interlocutor. O mesmo tipo de procedimento é utilizado para censurar o comportamento de uma outra personagem: Cótilo. No epigrama 2.70, o facto de fazer questão de ser o primeiro a entrar no solium gera automaticamente suspeitas de atitudes devassas:

Non uis in solio prius lauari quemquam, Cotile: causa quae, nisi hnec est, undis ne fouearis irrumatis?

Primus te licet abluas, necesse est ante hic mentula quam caput lauetur.

«Não queres que na piscina quente se lave antes de ti quem quer que seja, Cótilo. Qual é a razão, se não esta: para te não esquentares em águas que chuparam pénis?

Nem que te laves em primeiro lugar, não tens outra hipótese, Senão aí lavar o membro antes de lavar a cabeça.»

No epigrama 2.81, o poeta interpela directamente Caridemo:

Iratus tamquam populo, Charideme, lauaris:

Inguina sic toto subluis in solio.

Nec caput hic uellem sic te, Charideme, lauare.

Et caput ecce lauas: inguina malo laues.

«Pareces irado com o povo, Caridemo, ao tomar banho: por toda a banheira mergulhas os genitais.

Não gostaria, Caridemo, que a cabeça aqui lavasses.

E eis que lavas a cabeça... Que laves os genitais prefiro.»

Zoilo, Cótilo e Caridemo apresentam em comum uma cabeça imunda, asquerosa. Encarnam o próprio vício e perversão de uma parte significativa da sociedade Romana do século I, que abandonou a austeridade dos antigos costumes em favor da prevaricação e da corrupção moral. Em suma, Roma sentiu no corpo os prazeres das águas termais; porém, os espíritos não lograram sair fortalecidos.

As palavras finais não serão nossas. Terminamos com o mais famoso epitáfio de Ti. Claudius Secundus, sobremaneira eloquente na sábia conclusão a tirar: «Banhos, vinho, e sexo arruínam os nossos corpos, mas são eles a essência da vida.». 